\title{
THEORETICAL ANALYSIS OF OCCUPATIONAL DEVELOPMENT ASPECTS FROM THE VIEWPOINT OF THE PERSONALITY'S CONSTANT INDIVIDUAL TRAITS CONCEPT
}

\begin{abstract}
The concept of personality's constant individual traits and its significance, as well as implications for problems connected with choosing an occupation have been presented in the paper. Selected theories of occupational development have been analyzed from the concept viewpoint and certain traits of occupational personality presented by authors of occupational development theories have been confronted with constant individual traits of personality.

Six types of J. Holland's occupational personality (i.e. realistic, investigative, artistic, social. industrious and conventional) have been analyzed. The number of kinds of each type has been calculated, after considering constant individual traits of personality.

It has been concluded that due to constant individual traits of personality the processes connected with choosing an occupation should be highly individualised. Possibility of applying the concept to preparing a list of occupations and typology of occupational careers has been pointed out. Including constant individual traits of personality among basic determinants of occupational success has been suggested.

Key words: occupation, occupational personality, occupational development, occupational success, concept, individual traits

\section{INTRODUCTION}

The concept of constant individual traits of personality (Wilsz 1996; 1997; 2001), whose theoretical base is formed by the theory of an autonomic system (Mazur, 1996), contributes important elements to the investigation mechanisms of man's functioning and his behaviour. Making use of the concept allows optimising human activities in different fields.

According to the concept, lasting differences among people amount to differences in magnitudes of their constant individual traits of personality, as all people have the same constant traits of personality, but their traits are not the same (they are of different magnitude). The amount of constant individual traits is determined by differences between magnitudes of the same individual constant traits in different people. There are also differences between their variable traits, however, they are not as durable and are easily changeable under influence of various external factors.
\end{abstract}

\section{THE AIM OF THE STUDY}

The aim of the article is to study occupational development aspects from the viewpoint of the personality's constant individual traits concept.

\section{THEORETICAL FRAMEWORK AND RESEARCH METHODS}

World literature on selecting an occupation and on problems of occupational development is very extensive. There are many different theories of occupational 
development describing, explaining and predicting man's occupational behaviour. However, each individual theory is based on different assumptions and focuses on different factors deciding on our choice of an occupation and conditioning occupational development. Individual theories isolate different determinants of the said factors. However, none of the theories can give sufficient theoretical grounds allowing professional solution of practical problems connected with vocational counselling.

To achieve the established goal, the theoretical analysis served as methodological basis to study occupational development aspects from the viewpoint of the personality's constant individual traits concept.

RESULTS

The concept of personality constant individual traits is based on a proved assumption that treating man as one of the general model within an autonomic system allows considering his or her personality as a set of individual, constant properties and variable properties. Constant individual traits of man's personality correspond, according to the first version of the concept, to constant steering properties of the autonomic system, whereas variable traits of personality correspond to variable steering properties of the system.

There was a division made in the concept of constant traits (i.e. independent of the environmental influence) and variable traits (i.e. influenced by the environment). In the first version of the concept, two groups of personality's constant individual traits are considered: information traits (intelligence, quick-wits, talent) and energy traits (dynamism, tolerance, susceptibility). In the second version of the concept, based on psychological theories, which is closer to psychological analysis of personality, there are the following traits distinguished among personality's constant individual traits: traits concerning intellectual functions and traits concerning interpersonal relations.

The traits in the intellectual field are as follows:

$\checkmark$ Processability is the perfection degree of the reflective/ intellectual sphere;

$\checkmark$ Reproducibility is the perfection degree of the perceptive-mnemonic sphere;

$\checkmark$ Talent is the perfection degree in a certain field of activity.

The traits in the field of interpersonal relations are

$\checkmark$ Emissivity, which is the totality of resources considered here, especially knowledge, ways of acting, socially significant symbols, etc.

- Positive emissivity is an inclination to emit resources to the environment,

- Negative emissivity is an inclination to draw resources from the environment.

$\checkmark$ Tolerance, which is the action extent of one's environment drawing unsolicited and adequate reaction of one's personality;

$\checkmark$ Susceptibility, which is the action extent of one's environment to which one's personality reacts adequately under pressure.

From the viewpoint of the personality's constant individual traits concept, man's behaviour depends on his personality's constant individual traits, on variable traits and a situation he is involved in. At the same time, an ideal situation for a man is the one that is wholly conformable with all these traits. Such conformance can occur when a man adapts himself to a situation or when a situation is adapted to a man. Both these possibilities can occur only in relation to variable traits. As for the constant individual traits, there is only a possibility of adapting a situation to a man. Any situation discordant to constant individual traits of man's personality is a conflict situation for him.

Knowledge of his constant individual traits allows man to determine kinds of situations that are most suitable for him, thus it provides him with advice as to which 
situations he should look for in order to achieve satisfaction, self-fulfilment and success. He will be guaranteed the above by situations complacent with his personality's constant individual traits, be they situations encountered in his private or in occupational life. As people gifted with their own constant individual traits of personality are elements of situations, conformity of a situation a man is in with his constant traits depends on magnitudes of his personality's constant individual traits. Actually, a complete conformity between constant individual traits of personality and a situation can be achieved when there is a possibility of creating a new situation that is appropriate to an individual man. It involves selecting participants for the situation from among men possessing traits required by the kind of situation and by the aforementioned man's traits for whom the situation is created.

The concept of personality's constant individual traits can be applied to solving problems occurring in the sphere connected with man's occupational activity. The most important problems among them are: preparation for choosing an occupation, choosing an appropriate profession, choosing a field of vocational education, choosing a course of education, choosing a course of occupational adaptation, choosing occupational development, etc.

An optimum choice of an occupation for a man requires comparing the set of constant individual traits of his personality with the traits indispensable to master the knowledge and skills necessary in the selected profession and properly perform the work appropriate for that profession. It is, therefore, necessary to consider relations between traits of personality and requirements of different groups of professions. Choosing an occupation should require fitting it to man's constant individual traits whereas the process of occupational adaptation can only involve fitting a man to a chosen profession within variable traits which include the knowledge necessary to perform a given profession. For example, the traits can be acquired during the process of occupational training.

Awareness of constant individual traits of man's personality for whom the choice of profession is made as well as awareness of constant individual traits of personality required for practising different professions are, therefore, indispensable. There should also be a system created to classify professions in consideration of the traits required for that profession.

There may be three possibilities in the relation between an occupation and constant individual traits of personality:

$\checkmark$ an occupation perfectly fitting all the traits;

$\checkmark$ an occupation partly fitting the traits;

$\checkmark$ an occupation that is completely unsuitable for the traits.

A man should not embrace professions that are completely unfit to his personality's constant, individual traits. Correctness of choosing an occupation totally fitting the man's traits is unquestionable. The second possibility (an occupation only partly fitting one's constant individual traits of personality) is the one that occurs most frequently. It involves determining the necessary conformity degree of those traits with the traits required by a given profession in relation to each individual trait. Taking an optimum position concerning that possibility is extremely difficult, although there is no alternative in the case when a man greatly talented in certain field has no alternative but one - that his profession be more or less closely related with that field.

The concept of personality's constant individual traits allows finding permanent factors that determine man's activity manifested in his behaviour. The factors that most precisely determine the activity are traits in interpersonal relations led by emissivity. 
Emissivity is a motivational property that is of essential importance in unification and organisation of man's activities and behaviour. Emissivity initiates, directs and gives dynamic character to the activity and behaviour. A configuration of relatively constant aspirations of man is, to a large extent, an expression of his emissivity. The degree to which a man makes his aspirations come true depends on his intellectual qualities, which determine the man's traits in terms of intellectual functioning.

Due to the character of influence emitted by people to their environment, it is possible to discuss their positive, negative or zero emissivity. Colloquially speaking, a man who passes to his environment more resources than he draws - regardless of the kind of the resources - has positive emissivity, whereas a man who draws more resources from his environments than he emits - has negative emissivity. A man with zero emissivity retains balance between emitted and drawn resources.

It should be suggested that emissivity be assumed as a basic determiner of man's activity and his behaviour in any kind of action undertaken in different fields of activity.

The closer man's activity approaches extreme values, the higher his activity is. At high positive emissivity, man's behaviour and evident activity often appears uncoordinated, chaotic, impulsive, changeable, naive, etc. This lack of co-ordination, chaos and lack of respect for principles form a certain rule here. In case of highly negative emission, lack of respect for regulations is a rule, however, increased activity is not expressed by chaos, but on the contrary - it is expressed by cunning, providence, suspicion, expansion, pragmatism, etc. It is like this, positive emissivity and activity resulting from it has a completely different genesis than negative emissivity and the activity resulting from it. Emissivity, therefore, allows for the difference and explains the two contradictory kinds of activity displayed by different people. Being able to tell the difference between these kinds of human activity is of extreme importance when determining for man a role to perform in the profession he practises (e.g. a role of a creator, interpreter, performer or an organiser) (Wilsz, 1996-97).

Apart from emissivity, other traits in the sphere of interpersonal relations include tolerance and susceptibility. The traits are especially important in professions oriented towards people, professions requiring interpersonal competence.

A man who has a freedom of choice prefers situations that are included within his range of tolerance, while he will cope with situations under constraint only within the limit of his susceptibility. It happens in such a way, within his limit of tolerance man accepts impulses of his own free will, regarding them all to be positive for him. Beyond the limit of his tolerance he accepts impulses under pressure. The further beyond his limits of tolerance the impulse, the higher his reluctance and for the pressure to be effective it must be much stronger. Susceptibility is a trait that determines effectiveness of pressure. When faced with impulses reaching beyond the limit of his tolerance and susceptibility, man will put up resistance that cannot be overcome and there is nothing that can make him succumb to the impulses.

Depending on an assumed scale for tolerance and susceptibility, it is possible to determine a definite number for types of people. Hence, for example, people who display high tolerance and susceptibility agree to almost anything, accepting a very wide range of human kinds of behaviour. They very seldom have conflicts with other people. On the other hand, people with low tolerance and susceptibility agree to very few things of their own free will and are very hard to persuade under pressure.

People who are managers and tutors should have a high tolerance level, but they should not have too high a level of susceptibility, not yield under pressure when they are 
not deeply convinced about the correctness of actions they were forced to take. Higher susceptibility is permissible and even required at times, in the case of subordinates who work under constant supervision of their superiors.

Constant individual traits of man's personality in the field of intellectual functioning are especially important for people whose work involves mainly data processing, who are characterized by creative thinking, who have the ability for independent decision making, and who desire permanent self-education, etc.

According to the concept of personality's constant individual traits, choosing an occupation involves constant traits of personality as the basic criterion. Similarly, the theories of occupational development (by, e.g. J. Holland, F. Parsons, A. Roe, D. Super, and the concept of Dictionary of Occupational Titles edited by the US Department of Labour), show that the structure of personality is also a very important indicator of success in an occupation. Other authors also mention such factors as stages of development or environmental conditioning. Links between those factors and personality are obvious. Some of them are directly influenced by personality; others directly influence personality, its development and relative degradation. Concepts and theories concerning selecting an occupation and occupational development (by, e.g. E. H. Ericson, E. Ginzberg, R. O’Hary, R. J. Havighurst, R. Hoppock, D. J. Levison, D. Tiedeman, E. H. Schein), considering different aspects of the processes, are also closely connected with man's psychic development. This development cannot be properly realized without proper knowledge of psychological problems of his personality.

There are also many personality theories in psychology. Having intrinsically analyzed basic theories of personality, experts on problems of personality, C. S. Hall and G. Lindzey (Hall, Lindzey, 1990), are very critical about them (Wilsz, 1996). It is their opinions that give grounds for maintaining that one is unable to solve the problems of man's functioning effectively on the grounds of the theoretical systems currently coexisting in the psychology of man and that "there is no general theory of man's psychic functioning, that considers the totality, all psychic functions and all forms of behaviour" (Gadalova, 1999).

Creating one general theory, including factors considered in all the most important theories of occupation and occupational development seems as unrealistic today as, according to psychologists, it is to try to create one general theory of man's psychic functioning. Lack of one general occupational development theory including all problems connected with: preparing one to choose his or her occupation, choosing an occupation, occupational development, etc., and considering the totality of external human factors and external factors surrounding man seems to be closely connected with lack of a general theory of man's psychological functioning.

Not all psychologists believe in a possibility of creating such a theory (J. Kozielecki maintains, for example, that "those who believe that as psychology matures, there will be let us say, within the next century - a general theory of personality and behaviour, which shall be accepted by the whole community of scholars, are mistaken" (Kozielecki, 1995)). In my opinion, it is impossible to create either a general theory of man's psychological functioning or a general theory of occupational development. We assume a general theory of occupational development should be included in the general theory of man's psychological functioning.

The theory of autonomic systems, which was originally called by Marian Mazur - its creator - the theory of independent systems, can play a role of a general theory of man's psychological functioning in the realm of his occupational activity as it considers all his 
problems connected with his psychological functioning and allows for explaining reasons, the course and interrelations of processes occurring in different fields of his activity.

After reviewing the most important world theories of occupational development presented in Polish reference sources (Wilsz, 2000), we would like to point out their personality aspects and analyze them from the view point of personality's constant individual traits.

Differences between individual theories involve mainly stressing different elements of the personality structure and other relations between personality and occupation.

When analysing the theory of traits and a coefficient by F. Parsons, from the viewpoint of the personality's constants individual traits concept, the constant formula of abilities and other traits of personality that forms the basic assumptions of the theory can be considered to be an equivalent of personality's constant individual traits. And it is both, in the theory and in our concept that one approaches selection of an occupation for a man after acquiring thorough knowledge of the man and reviewing the occupations in terms of his constant, individual traits of personality (it would be ideal, of course, if the man, after getting to know himself, could chose an occupation best suited to his personality). In our opinion, the theoretical basis formed by the theory of autonomic systems and the concept of personality's constant individual traits will prove charges of its inappropriateness aimed at it to be futile and confirm its correctness.

As for J. Holland's theory, its analysis from the viewpoint of the personality's constant individual traits concept induces discussion, mainly concerning classifying people into six types of occupational personality (realistic, inquisitive, artistic, social, enterprising and conventional). J. Holland's characteristics of the personality's six types and his personality categories as well as environmental traits are somewhat incomplete. In spite of creating additional mixed types, combined of the six dominant types, they do not take into account numerous types of personality functioning in real life and other types of occupational environments. J. Holland's theory reflects certain areas of personal orientation preferred by man very well. It does not, however, explain the genesis of the occurring phenomena and processes or their mutual relationships. "It is a descriptive theory reflecting how things are, but not explaining what things, why they occur, or what they affect" (Bańka, 1995). The concept of personality's constant individual traits provides arguments that justify correctness of objections aimed against J. Holland's theory, for example by the quoted author, A. Bańka.

If one assumes just the three-step scale for the five traits and five-step scale for one (emissivity) - one obtains 1215 different types of personality named in the concept of constant, individual traits of personality and each of them has different occupational preferences. Individual traits of occupational personality proposed by J. Holland can be attributed with definite quantities of constant, individual traits of personality. For example, in case of an inquisitive type they will be mainly processability, reproducibility and talent; in case of an artistic type they will certainly include talent and emissivity, whereas in case of a venturesome type - emissivity.

Therefore, as each man has six constant individual traits of personality, J. Holland's types of personality must be considered incomplete.

For example, a realistic type can have different quantities of processability, reproducibility, talent, tolerance and susceptibility as well as three quantities of emissivity. Hence, on the grounds of the concept of constant, individual traits of personality, it is possible to distinguish not one, but 729 kinds of personality of a realistic type. 
An inquisitive type should include at least two strong traits of personality in the area of psychic functions at the same time. When discussing traits in the field of interpersonal relations, all possible values of its magnitude are allowable, therefore, there can be 135 types of an inquisitive personality.

As for the artistic types, to be able to determine the number of this kind of types, one should decide whether the artistic type should have only a great talent, or it may be just a mediocre talent. Should the second trait, apart from talent in the field of psychic functions (processability), also be great or should this type just have a large positive emissivity or, eventually, should he possibly have medium, positive emissivity as well. If we assume that it should be only great positive emissivity and only great processability as well as a great talent, we shall get 27 kinds of this type of personality.

As for a social type, there can be 540 kinds of personality of this type.

Assuming that an industrious type is determined only by emissivity, we can forecast, that out of all five kinds of emissivity people, zero emissivity will turn out to be the least industrious. However, genesis and character of positive and negative industriousness are different. Including those who have both, medium and large, positive and negative emissivity, we get 972 kinds of this type of personality.

Assuming that only people with zero emissivity are included in the conventional type, we will have to deal with 243 kinds of the type.

Should one analyze the 729 kinds of realistic type, 135 kinds of inquisitive type, 27 kinds of artistic types, 540 kinds of social types, 972 kinds of industrious types and 243 kinds of conventional types, obtained as a result of applying the concept of constant, individual traits of personality, it turns out that certain kinds of types occur (recur) in all six groups. It may happen, for example, that an inquisitive type will also be a realistic, artistic, social, industrious and conventional type, whereas, a realistic type can turn out to be an inquisitive, social and conventional type, etc.

A. Roe mentions a way of consuming psychic energy that has definite implications in occupational activity.

The way of consuming psychic energy depends on all constant individual traits of personality, whereas among the traits involved in psychic functioning the most important are processability and talent. As for traits important in the field of interpersonal relations, emissivity seems to be of strategic importance. People gifted with positive emissivity have surplus energy which they emit to their environment, whereas the more intensive the emissivity the more surprising and shocking the ways of its transmission. People with negative emissivity are not very generous in transmitting psychic energy to their environment. They do it only when they are forced to do it, in the sense that, thanks to their own transmitted energy they gain indispensable energy from the environment, which lets them recompense deficiency in energy produced by their own organism.

A. Roe's theory and the concept of occupational development worked out by the U.S. Department of Labour have certain common aspects.

A. Roe distinguishes two categories of occupations: people oriented occupations and non-people oriented occupations, whereas according to the concept worked out by the U.S. Department of Labour traits of personality and occupational traits make a showing in the realms of human activity pertaining to: data, people or objects.

In case of people-oriented occupations, constant individual traits of personality in the field of interpersonal relations, like emissivity, tolerance and susceptibility, are the most important. 
Emissivity is very important here in the sense of non-conflicting (actually, as nonconflicting as possible) work with people in different situations, depending on one of the three possible configurations of their emissivity:

- a configuration that occurs in people of the same or similar emissivity (e.g. two cooperating people of zero emissivity);

- a configuration that occurs in people of contrary emissivity (for example one man of high positive emissivity and another of high negative emissivity);

- a configuration that occurs in people of sequent emissivity (e.g. one individual of medium positive emissivity and another one, who has zero emissivity).

The first configuration is best for solidarising with other people and is desirable in people realising common goals because with this kind of configuration they can make use of the sum of their powers, which leads to the increase of effectiveness.

The second configuration should occur when one man is required to be protective towards the other. Then, the first man can pass his experience to the other and the other man can make use of it (such configuration should occur between a superior and his or her subordinate).

The third configuration is bad for co-operation between people although they often like each other.

Tolerance and susceptibility are of great importance to people who work in people oriented occupations. Great tolerance should certainly characterize people who are managers and tutors. They should not, however, display excessively high susceptibility. Higher susceptibility is allowed and at times even recommendable in subordinates (Wilsz, 1996).

As for D. Super's theory, one should approve of his opinion that the process of occupational development is a compromise between individual factors of man and factors that man encounters in his/ her environment. It is in accordance with the opinion we have expressed earlier, that "man will do best in an occupation completely suited to his unformable traits of personality and suited to all his traits of personality". In practice, however, "after analysing and confronting traits that man has with traits required for individual occupations one should choose an occupation or a group of occupations ensuring the highest conformability of traits possessed by an individual with those required in a given occupation" (Wilsz, 1995).

Coming back to D. Super's theory - similarly to what we have tried to point out in relation to the theory presented by F. Parsons - the concept of constant, individual traits of personality confirms its basic assumptions.

The concept of personality's constant individual traits could be used for creating a classification of occupations. It might also enrich typology of occupational careers as the traits, due to their function, can be regarded as basic determinants of occupational success. Correctness of the thesis, that there is a relationship between occupational success and constant individual traits of personality may be justified by analysing occupational careers of various well-known people. The analysis reveals that occupational success is greater the higher the degree of conformability of the traits to the traits required by an occupation they perform.

\section{CONCLUSIONS}

So, one can say that preparation of an individual to choose an occupation, choice of a well-suited profession, choice of an appropriate course of occupational education, the course of the education, the process of occupational adaptation, occupational development 
of man, etc., should be an individualised process due to his or her constant individual traits of personality.

This research will contribute to the deepening of scientific researches on the concept of personality's constant individual traits and its significance, as well as implications for problems connected with choosing an occupation and possibility of applying the concept to preparing a list of occupations and typology of occupational careers.

\section{REFERENCES}

1. Bańka, A. (1994). Zawodoznawstwo, doradztwo zawodowe, pośrednictwo pracy. Psychologiczne metody $i$ strategie pomocy bezrobotnym [Science of occupations, occupational counselling, labour exchange. Psychological methods and strategies of helping the unemployed]. Poznan : Wydaw. Print-B, p. 288 (in Polish).

2. Hall, C.S., Campbell, John B., Lindzey, G. (1966). Teorie osobowości [Theories of personality]. Warszawa : Wydawnictwo Szkolne PWN, p. 688 (in Polish).

3. Mazur, M. (1996). Cybernetyczna teoria układów samodzielnych [Cybernetic theory of independent circles]. Warszawa : Wydawnictwo Szkolne PWN, p. 231 (in Polish).

4. Nowacki, T. (1999). Zawodoznawstwo [Science of occupations]. Radom : ITeE, p. 296 (in Polish).

5. Skłodowski, H. (1999). Psychologiczna problematyka doradztwa zawodowego [Psychological problems of occupational counselling]. Łódź : Wydaw. Uniwersytetu Łódzkiego, p. 270 (in Polish).

6. Wilsz, J. (1996-97). Mechanizmy samoregulacji w systemie ksztatcenia [Mechanisms of self-regulation in the system of education]. Częstochowa : Wydawnictwo Wyższej Szkoły Pedagogicznej, p. 246 (in Polish).

7. Wilsz, J. (2000). Osobowościowe aspekty teorii rozwoju zawodowego w kontekście koncepcji stałych indywidualnych cech osobowości [Personality aspects of the theory of occupational development in the context of the concept of constant individual traits of personality]. In : Lewowicki, T., Wilsz, J., Ziaziun, I., Nyczkało, N. (Eds.). Kształcenie zawodowe: pedagogika i psychologia, No 2, Częstochowa-Kijów, p. 247-265 (in Polish).

8. Wilsz, J. (1987). Prognozowanie rozwoju parametrów charakteru uczniów w celu optymalnego wyboru przyszłego zawodu [Forecasting development of parameters of characters of students aimed at optimum selection of their future occupation]. Szkoła Zawodowa, No 1, p. 14-19 (in Polish).

9. Wilsz J. (1999). Przemiany edukacyjne $\mathrm{z}$ punktu widzenia podejścia systemowego i koncepcji stałych indywidualnych cech osobowości człowieka [Educational changes from the point of view of the systemic attitude and the concept of man's constant individual traits of personality]. In : Lewowicki, T., Wilsz, J., Ziaziun, I., Nyczkało, N. (Eds). Kształcenie zawodowe: pedagogika i psychologia, No 1, Częstochowa-Kijów, p. 69-87 (in Polish).

10. Wilsz, J. (2001). Psychologizowana wersja koncepcji stałych indywidualnych cech osobowości i jej wykorzystanie przy wyborze zawodu [Psychological version of the personality's constant individual traits concept and its use in choosing a profession]. In : Lewowicki, T., Wilsz, J., Ziaziun, I., Nyczkało, N. (Eds.). Ksztatcenie zawodowe: pedagogika i psychologia, No 3, Częstochowa-Kijów, p. 405-415 (in Polish). 
11. Wilsz, J. (1987). Rola właściwości sterowniczych przy rozwiązywaniu problemów kadrowych [The role of steering properties in solving human resources problems]. Humanizacja Pracy, No 3, p. 44-54 (in Polish).

12. Wilsz, J. (2009). Teoria pracy. Implikacje dla pedagogiki pracy [The theory of labour. Implications for labour pedagogy]. Kraków : Oficyna Wydawnicza "Impuls", p. 523 (in Polish).

13. Wilsz, J. (1996). Znaczenie stałych indywidualnych cech osobowości człowieka w procesie kształcenia przedzawodowego [The importance of constant individual traits of personality of man in the process of pre-occupational training]. In Jakowicka, M., Uździcki, K. (Eds.). Edukacja ogólnotechniczna na przełomie XX i XXI wieku : praca zbiorowa z okazji 70-lecia urodzin i 48-lecia pracy zawodowej prof. zw. dra hab. inż. Kazimierza Uździckiego Częstochowa, p. 215-226 (in Polish).

14. Вільш, I. (1998). Врахування сталих індивідуальних рис особистості як важливий аспект гуманізації навчання й виховання [Considering constant individual traits of personality as an important aspect of humanisation of education and upbringing]. Педагогіка і психологія, № 2, Київ, p. 61-68 (in Ukrainian).

15. Вільш, I. (1999). Концепція сталих індивідуальних рис особистості та ії використання у деяких практичних сферах [The concept of constant individual traits of personality and its application to certain practical problems]. Практична психологія та соиіальна робота, № 1, p. 2-6 (in Ukrainian).

16. Вільш, І. (1997). Структура, зміст і функції сталих індивідуальних якостей учня у процесі допрофесійного навчання і виховання [The structure, content and functions of constant individual qualities of a student in the pre-professional training and education]. Abstract of thesis for a Doctorate' Degree in Pedagogical Sciences Київ, p. 53 (in Ukrainian).

17. Вільш, І. (1999). Сукупність сталих індивідуальних рис особистості як критерій обрання професії та функціональної роли в іï межах [Constant individual traits of personality as a criterion for choosing an occupation and role within its limits]. In : Ничкало, Н. (Ed). Сучасна вища школа: психолого-педагогічний аспект, Київ, р. 60-77 (in Ukrainian). 